И. В. Костиковой; [2-е изд., перераб. и доп.]. М. : Аспект-Пресс, 2005. $255 \mathrm{c}$.

2. Визгина А. В., Пантилеев С. Р. Проявление личностных особенностей в самоописаниях мужчин и женщин. Вопросы психологии. 2001. № 3. С. 91-100.

3. Горностай П. П. Диагностика и коррекция ролевых конфликтов. Журнал практического психолога. 1999. № 1. С. 44-51.

4. Каширская И. К. Социально-психологический анализ основных источников информации и процесс гендерной социализации. Bonpocbl психологии. 2003. № 6. С. 8-11.

5. Літвінова О.В. Вплив гендерних стереотипів на професійне самовизначення : теоретичний аспект. Наукові Записки Ін-ту психологіi ім. Г. С. Костюка АПН Украӥни; За ред. С. Д. Максименка. К. : Главник, 2005. Вип. 26. Т. 3. С. 3-7.

DOI https://doi.org/10.30525/978-9934-588-80-8-1.16

\title{
ОСОБЕННОСТИ ОСОЗНАННОСТИ КАК ПРОЦЕССА И МЕТОДА
}

\author{
Мединцов И. В. \\ аспирант кафедры общей психологии \\ Киевский национальный университет имени Тараса Шевченко \\ 2. Киев, Украина
}

Для того, чтобы определенная процедура вошла в арсенал эмпирической клинической психологии, в настоящее время требуются две вещи: технология должна быть достаточно четко определена и должна оказаться полезной при надлежащем применении. Эти требования важны, но в конечном итоге недостаточны. Бывают случаи, когда технологии настолько эфективны, что одно только их воздействие оправдывает их положение, но в более естественной ситуации прогресс в этой области требует включения этих технологий в один или несколько научных отчетов по психопатологии для наличия доказательств важности указанных процессов и принципов.

Эмпирическая клиническая психология значительно недооценила эти моменты, но долгосрочный эфект такого подхода становится все более очевидным. Без научно-понятных процессов и принципов данные о технологиях собираются в постоянно растущую совокупностть без 
возможности для упрощения и организации. Списки эмпирически обоснованных методов терапии легко могут включать несколько вариантов одного и того же процесса. Если нет спроса на данные, показывающие характерный и теоретически последовательный процесс (а не только данные о результатах), то тривиальные различия между процедурами могут бесконечно умножать диапазон эмпирически поддерживаемых технологий, но без какого-либо увеличения фактического воздействия науки на терапию.

Осознанность (mindfulness) включает в себя «полное внимание к настоящему опыту в данный момент времени» по Марлат и Кристелера [7] и как «направление внимания определенным образом: намеренно, в данном моменте, безоценочным образом» в интерперетации КабатЗинна [4]. Природа осознанности с точки зрения, например, Лангер [5], сильно отличается от осознанности с точки зрения Кабат-Зинна. В центре когнитивных и метакогнитивных процессов лежит человеческий язык, который по своей сути является двунаправленным и часто оценочным [10]. Он двунаправлен в том смысле, что является ссылочным или реляционным. Если указано, что объект называется х, то можно вывести из этого, что х - это тот объект - выведение, которое могут выполнить младенцы в возрасте 17 месяцев [6]. Иной важный аспект: люди могут беспокоиться о своем поведении; сравнивать себя или партнера неблагоприятно с идеалом; сравнивать настоящее с концептуализированным прошлым или с боязливым или благосклонным будущим. Когнитивные процессы такого рода вовлечены также в сексуальную дисфункцию человека [8] и являются мишенью для эмпирически поддерживаемого лечения сексуальной дисфункции [1]. Исследования Хаес, Вилсон, Гифорд, Фолет и Стросахл подтверждают, что это в свою очередь связано с процессом избегания опыта и существует значительный объем доказательств того, что избегание опыта вредно во многих психопатологических областях [11]. По мере того, как происходит избегание опыта, возрастает вероятность стресса и возбуждения, что, в свою очередь, приводит к более оценочным вербальным сопоставлениям, а также к более сфокусированным на себе стратегиям избегания. Хаес утверрждает, что этот процесс в конечном итоге может быть самокорректирующим, если бы не то, что поведение (регулируемое вербальными правилами) имеет тенденцию быть относительно негибким и жестким [9]. Также люди это исторические организмы,которые добавляют к объектам новые функции и тем самым реконтекстуализируют существующие функции [2]. Голдиамонд указывает, что старомодная мудрость конструктивного подхода [3] (самого основания ранних функциональных, поведенческих 
данных) была в значительной степени забыта в эмпирических клинических кругах, отчасти потому, что язык психиатрических синдромов является языком болезней, которые должны быть устранены.

Несмотря на наличную совокупность эмпирических данных о специфике осознанности как процесса и метода, в нашей статье совершен теоретический анализ особенностей этих данных и определены важные моменты для корректировки как клинического контекста применения осознанности, так и контекста понимания общей психологии.

Многие формы широко принятого эмпирически обоснованного лечения имеют очень ограниченные данные, поддерживающие характерный и теоретически последовательный процесс. Осознанность (mindfulness) находится в несколько схожей ситуации в настоящее время. Процедура уточняется, и есть данные, подтверждающие ее эфективность, но ее научный анализ еще не раскрыл и половины всей специфики. Никакой научный анализ пока не кажется адекватным для учета влияния осознанности, но начальные попытки уже предприняты. Тем не менее, имеющиеся отчеты сильно различаются, и данные несколько ограничены.

Все это неудивительно, потому что осознанность - это преднаучная концепция и поэтому ее развитие на данном этапе не должно быть научно последовательным. Однако, если мы хотим, чтобы исследования в области осознанности продвигались вперед, эта проблема должна быть решена. Буддизм - это преднаучная система. Его постулаты и принципы не являются научными постулатами и принципами. Более значительный прогресс требует понимания на серьезном научном уровне.

Использование специфических процессов и аспектов применения осознанности представляют собой важную проблему эмпирической клинической психологии, поскольку их более масштабная цель просто не совпадает с более распространенными методами, которые они могут заменить. Эти новые методы - конструктивны.

Они направлены на увеличение диапазона и гибкости поведения, возникающего в контекстах, в которых ранее работали только буквальные, избегающие или оценочные функции. Они несут в себе то же послание, что и старомодная, функционально ориентированная поведенческая терапия, но в новом виде, который утверждает и удостаивает внимания важность человеческих мыслей и чувств и их роль в человеческих страданиях. Если этот анализ верен, то исследователи и терапевты, возможно, видят более фундаментальные 66 
изменения, чем предполагают некоторые из разработчиков этих методов. Осознанность, принятие и расцепление - это не просто другой способ лечения традиционно концептуализированных проблем депрессии или тревоги. Они подразумевают новое определение проблемы, ее решение и то, как следует измерять и то, и другое. Проблема заключается не в наличии конкретных мыслей, эмоций, ощущений или побуждений: Это ограничение человеческой жизни. Решение не в том, чтобы устранять трудные частные события: а в том, чтобы жить полноценной жизнью.

\section{Литература:}

1. Бах А. К., Винсче Дж. П., Барлоу Д. Х. Сексуальная дисфункция. Клинический справочник психологических расстройств: пособие по последовательной терапии [Sexual dysfunction. Clinical handbook of psychological disorders: A step-by-step treatment manual]. Нью-Йорк: Гилфорд Пресс. 2001.

2. Вилсон К. Г., Робертс М. Ключевые принципы в терапии принятия и ответствености: приложение к анорексии [Core principles in Acceptance and Commitment Therapy: An application to anorexia]. Когнитивная и бихевиоральная практика, 2002. № 9. С. 25-32.

3. Голдиамонд И. В направлении конструктивного подхода к социальным проблемам [Toward a constructional approach to social problems]. Бихевиоризм, 1974. № 2. С. 1-79.

4. Кабат Зинн Дж. Куда бы ты не шел, ты уже там: Медитация осознанности в повседневной жизни [Wherever you go, there you are: Mindfulness meditation in everyday life]. Нью-Йорк: Гиперион. 1994.

5. Лангер И. Дж. Осознанность [Mindfulness]. Чтение, МА: Эдисон Весли. 1989.

6. Липкенс Г, Хаес С. К., Хаес Л. Дж. Лонгитюдное исследование стимульных реакций у детей [Longitudinal study of derived stimulus relations in an infant]. Журнал экспериментальной детской психологии, 1993. № 56. C. 201-239.

7. Марлат Г. А., Кристеллер Дж. Л. Осознанность и медитация. Интегрируя духовность в терапию [Mindfulness and meditation. Integrating spirituality into treatment]. Вашингтон, ДС: Американская психологическая ассоииаџия. 1999.

8. Нобре П., Гувейа Дж. П. Эректильная дисфункция: эмпирический подход основанный на когнитивной теории Бека [Erectile dysfunction:An empirical approach based on Beck's cognitive theory]. Терапия сексуальности и отношений, 2000. № 15(4). С. 351-366. 
9. Хаес С. К. Поведение основанное на правилах: Познание, случайности и контроль [Rule-governed behavior: Cognition, contingencies, and instructional control]. Нью-Йорк: Пленум Пресс. 1989.

10. Хаес С. К., Барнес-Холмс Д., Роше Б. Теория реляционных фреймов: пост-скинерианская ситуация человеческого языка и познания [Relational frame theory: A post-Skinnerian account of human language and cognition]. Нью-Йорк: Пленум Пресс. 2001.

11. Хаес С. К., Вилсон К. В., Гиффорд И. В., Фолетт В. М., Стросахл К. Эмоцилнальное избегание и поведенчиские расстройства: функциональный измерительный подход к диагностике и терапии [Emotional avoidance and behavioral disorders: A functional dimensional approach to diagnosis and treatment]. Журнал консультирование $u$ клинической психологии, 1996. № 64. С. 1152-1168.

DOI https://doi.org/10.30525/978-9934-588-80-8-1.17

\title{
ВАЖЛИВІСТЬ ПСИХОЛОГІЧНОГО ТА ФІЗИЧНОГО ЗВ'ЯЗКУ МІЖ ДИТИНОЮ ТА ОПІКУНОМ
}

\author{
Самагальська Е. Н. \\ бакалавр, \\ студент факультету прикладних наук \\ Академії ВСБ в Домброві Гурнічій \\ Домброва Гурніча, Польща
}

Багато батьків вважають, що немовля «нічого не розуміє», і те, як пройде ранне дитинство не вплине на особистість дитини та іiі подальше життя. Все більше батьків, їдучи на заробітки, залишає своїх дітей на бабусь та дідусів, що вказує на актуальність даної тематики. Ще одним важливим аспектом дослідження $є$ проблема соціалізації дітей, котрі з дитинства живуть в дитячих будинках без батьків.

Метою дослідження $є$ поглиблення знання людей в темі зв'язків між батьками та дітьми. Допомогти зрозуміти важливість дорослих у житті дітей та посприяти позитивним змінам у виховних процесах, які відбуваються у дитячих будинках.

Теорія прив'язаності разом з іiі застосуваннями в різних галузях на сьогодні $\epsilon$ найбільш широко і найбільш інтенсивно розробленою теоретичною основою. Започаткована в 1950 -х роках лікарем та психоаналітиком за освітою, Джоном Боулбі у Великобританії. Свої праці він 68 